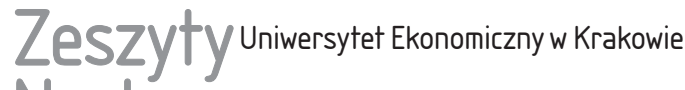 Naukowe
}

$1(925)$

ISSN 1898-6447

Zesz. Nauk. UEK, 2014; 1 (925): 127-138

\section{Anna Staszel}

Studia Doktoranckie Wydziału Finansów

Uniwersytet Ekonomiczny w Krakowie

\section{Historia rachunkowości - jednej z najstarszych dyscyplin ekonomicznych}

\section{Streszczenie}

Przejawy rachunkowości można znaleźć już w czasach prehistorycznych, kiedy to stanowiła ona esencję ówczesnej myśli ekonomicznej: rozwiązywała problemy związane ze wspólną pracą. W niniejszej publikacji przedstawiono historię rachunkowości, począwszy od pierwszego konta księgowego, poprzez przełomowe dzieło Luki Paciolego, po ewolucję rachunku kosztów stworzonego na potrzeby pierwszych kapitalistów. Praca traktuje nie tylko o badaniach naukowych dotyczących systemu rachunkowości, lecz również o oszukańczej sprawozdawczości finansowej i powołaniu zawodu biegłego rewidenta. Historia rachunkowości wskazuje, że jest to jedna z najstarszych dyscyplin wśród nauk ekonomicznych, a co przy tym najważniejsze: jej założenia wytrzymały próbę czasu: struktura konta księgowego ze stroną WN i MA pozostaje niezmienna od ponad pięciu tysięcy lat.

Słowa kluczowe: rachunkowość, konto, zasada podwójnego zapisu, historia ekonomii.

\section{Wprowadzenie}

W 1494 r. zostało po raz pierwszy wydane wielkie dzieło Luki Paciolego: Summa de arithmetica, geometria, proportioni et proportionalita. Wydarzenie to zostało uznane za historyczny początek rachunkowości. Jednakże rachunkowość, będąca dziełem intelektu człowieka, istniała już od zarania cywilizacji. Niektórzy 
miłośnicy rachunkowości, do których autor niniejszej pracy również się zalicza, posuwają się nawet do stwierdzenia, że pismo rozwijało się na potrzeby szeroko rozumianej rachunkowości: potrzeba wspomożenia zawodnej ludzkiej pamięci za pomocą zapisów przyczyniła się do powstania zaczątków stopniowo rozwijanej i doskonalonej rachunkowości. Świadectwem takiego podejścia mogą być słowa jednej z ksiąg Starego Testamentu - z Mądrości Syracha: „Cokolwiek przekazujesz, niech będzie pod liczbą i wagą, a dawanie i odbieranie - wszystko na piśmie” [Syr 42,7]. Z pewnością rachunkowość powstała z potrzeby „skwantyfikowanego określenia przejawów działalności gospodarczej” [Micherda 2001, s. 9]. Stąd można wnioskować, że w początkach cywilizacji ludzkiej rachunkowość stanowiła esencję myśli ekonomicznej, niezbędnej do rozwiązywania problemów związanych ze wspólną pracą [Dobija i Jędrzejczyk 2011]. Celem niniejszego artykułu jest przedstawienie najważniejszych faktów i etapów rozwoju rachunkowości, dyscypliny, której podstawowe założenia wytrzymały najtrudniejszą próbę: próbę czasu, gdyż struktura konta księgowego ze stroną Winien (Wn) i Ma jest niezmienna od ponad pięciu tysięcy lat.

\section{Początki cywilizacji ludzkiej a rachunkowość}

Wczesne formy społeczności ludzkiej borykały się z niezwykle ważnym problemem, decydującym o jej przetrwaniu, a mianowicie problemem współpracy. W czasach prehistorycznych, w samych początkach tworzenia się cywilizacji ludzkiej, ta kwestia miała kluczowe znaczenie. Dzięki wspólnej pracy społeczność uzyskiwała większe korzyści, a także ponosiła mniejsze koszty niż w przypadku działań indywidualnych. Jednakże trzeba było również znaleźć sposób na pomiar wkładu wnoszonego przez każdego członka społeczeństwa, a następnie metodę proporcjonalnego podziału efektów wspólnej pracy. Powstanie pierwszej rachunkowości było zapewne rozwiązaniem przedstawionych wyżej problemów pierwszych ludzi. Archeolodzy odkryli gliniane bryłki różnych kształtów, zwane tokenami, na których to opierały się rozliczenia gospodarcze już w VI tysiącleciu p.n.e. [Schmandt-Besserat 2007]. Pracownik za wykonaną pracę otrzymywał token symbolizujący produkt, który miał otrzymać jako zapłatę za pracę. Token ten spełniał podwójną rolę, gdyż był zarazem zobowiązaniem do wydania produktu. Stanowił on więc odzwierciedlenie dualizmu zdarzeń gospodarczych. Prace archeologów potwierdzają istnienie wczesnych form rachunkowości w Mezopotamii, Egipcie, Syrii, na Peloponezie i nawet w Indiach [Dobija i Jędrzejczyk 2011]. Pisarze i rachmistrze prowadzili tam powszechną działalność. Nowoczesny i precyzyjny system rachunkowości istniał np. w fabryce tkanin w mieście Ur trzy tysiące lat przed narodzeniem Chry- 
stusa. Sumeryjscy księgowi stosowali pojęcie roboczodniówki, a także potrafili sumować nakłady pracy [Struwe 1969]. Można więc uznać, że pieniądze na początku cywilizacji były traktowane abstrakcyjnie, jako zapis księgowy należności z tytułu pracy [Dobija i Jędrzejczyk 2011]. W Sumerze można spotkać także apogeum rozwoju rachunkowości starożytnej w postaci rachunku kosztów: rejestrowano przebieg produkcji w poszczególnych jej fazach i śledzono koszty przetworzenia. Wszystkie zapisy księgowe opierały się na ustalonej wewnętrznej jednostce miary. Prowadzono także miesięczne zestawienia. Było również coś, co można by uznać za konto księgowe: pierwszą pozycją na „koncie” była pozostałość sukna z ubiegłego okresu, następnie po stronie Wn księgowano poszczególne dostawy, a po przeciwległej stronie Ma - rozchód materiału. Również świat starożytnych Greków cechowała rozbudowana rachunkowość. Jak pisze historyk A. Krawczuk [1995], epoka mykeńska cechowała się pedantyczną działalnością biurową: ówczesną scentralizowaną gospodarkę kontrolowali liczni urzędnicy, sporządzając całe tomy rachunkowej dokumentacji. Mykeńczycy, mimo iż nie znali monet, to potrafili ściśle ewidencjonować zarówno należności, jak i posiadany majątek.

Badacze przeszłości szacują, że zawód księgowego pojawił się trzy tysiące lat przed naszą erą [Tumieniew 1969]. Budżetowanie stosowali już starożytni Grecy i Rzymianie. W 1905 r. odkryto manuskrypt z Indii z ok. 300 roku p.n.e., który zawierał wiele zagadnień z zakresu ekonomii i rachunkowości. Również w pismach hinduskich, w „Pieśni Pana” można wyczytać: „Jestem Prahlajdą wśród Dajtjówi/Czasem wśród rachmistrzów (...)" [Dobija i Jędrzejczyk 2011]. Tak więc rachmistrze, obok sławy, piękna, dobroci, stałości i mądrości również wymienianych w tej pieśni, stanowią istotę Najwyższego. Jest to chyba największa nobilitacja pracy księgowych, przynajmniej literacka.

Należy zapytać, dlaczego rachunkowość podwójna, czyli taka, jaką znamy współcześnie, nie powstała np. w starożytnym Rzymie czy Grecji. Stało się tak, ponieważ istnieje siedem warunków niezbędnych do rozwoju rachunkowości podwójnej [Alexander 2002]. Są to: własność prywatna, kapitał, handel, kredyt, pismo, pieniądz i arytmetyka. Zapisu podwójnego można już co prawda dopatrywać się w starożytnej Grecji czy Rzymie, gdzie bankierzy prowadzili chronologiczną ewidencję w dzienniku, a następnie zapisy przenosili do księgi głównej, gdzie każdy klient miał rachunek ze stroną Debet i Kredyt. Jednakże stosowanie takiego podwójnego zapisu nie stanowi jeszcze o rachunkowości podwójnej, starożytni nie znali najprawdopodobniej wymiarów i zastosowań zasady podwójnego zapisu. Trudno natomiast powiedzieć cokolwiek o rozwoju rachunkowości w pierwszych wiekach po narodzinach Chrystusa, gdyż nie ma dowodów historycznych z tamtych czasów, które mogłyby stanowić podstawę do rozważań na temat rozwoju rachunkowości. 


\section{Rozwój rachunkowości w średniowieczu i epoce odrodzenia}

W procesie rozwoju rachunkowości istotną rolę odegrał okres średniowiecza [Podstawy rachunkowości... 2006], kiedy to rozwijały się stosunki handlowe miast włoskich z krajami śródziemnomorskimi oraz bliskiego i dalekiego wschodu. Kupcy włoscy i bankierzy prowadzili coraz bardziej skomplikowane transakcje finansowe $\mathrm{i}$ handlowe, a to wymagało zapisywania w księgach nazwisk dłużników, kwot, terminów wymagalności, a następnie adnotacji o zapłacie. Zapisy dotyczące powstania należności, a następnie jej uregulowania przekreślano pionową linią, co znaczyło zakończenie transakcji - w ten oto sposób powstało pierwsze konto księgowe - konto dłużników. Pod koniec XIII w. pojawiły się także konta służące do ewidencji majątku: np. towarów. Księga kupiecka, powstała ok. 1400 r., stanowi pierwotną formę rachunkowości pojedynczej. W XIV w. w miastach północnych Włoch pojawiła się księgowość podwójna, wówczas zwana systemem weneckim lub systemem księgowości prowadzonej w dwu księgach [Podstawy rachunkowości... 2006]. Zapisy były dokonywane na początku w układzie chronologicznym w dzienniku, z którego później przenoszono je do księgi głównej, zawierały konta z podziałem na stronę debetową i kredytową. Na tym samym podziale, zwanym zasadą podwójnego zapisu, oparte jest funkcjonowanie kont współczesnej rachunkowości.

Autorem pierwszych opracowań naukowych dotyczących zasad prowadzenia księgowości był Benedetto Cortugli. W 1458 r. skończył on rękopis Della Mercantura et del Mercante perfetto, czyli $O$ handlu i kupcu doskonałym. Opisał on w nim podstawy księgowości, w tym także zasadę podwójnego zapisu, jednakże jedynie pobieżnie. Jego praca drukiem ukazała się dopiero w 1573 r., dlatego też za pierwsze i zarazem bardziej cenione dzieło mówiące o rachunkowości podwójnej uznaje się Summa di arithmetica, geometria, proportioni et proportionalita, czyli Zasady arytmetyki, geometrii, proporcji i proporcjonalności Luki Paciolego wydane w 1494 r. w Wenecji.

Luca Pacioli, francuski człowiek renesansu, urodził w 1445 r. w Toskani. W 1464 r. przeniósł się do Włoch, gdzie wykładał na Uniwersytetach w Perugii, Neapolu czy Rzymie aż do swojej śmierci w 1517 r. Summa di arithmentica... była pierwszym wydanym tekstem Paciolego, później napisał on także Divina proportione i tłumaczył matematyczne rozprawy Euklidesa.

Zakonnik i matematyk Luca Pacioli przedstawił zasady rachunkowości podwójnej w sposób naukowy i usystematyzowany, omówił zasady sporządzania inwentarza, rachunku zysków i strat, bilansu obrotów i bilansu sald wszystkich kont [Pacioli 2007 (1494)].

Ostatnia część obszernego, matematycznego traktatu Paciolego traktuje o rachunkowości. Według autora trzy najważniejsze rzeczy, które są potrzebne 
ludziom do należytego prowadzenia handlu, to pieniądz w gotówce, majątek oraz kredyt. Widać tutaj podobieństwo do współczesnego bilansu, w którym kapitał dzieli się na własny i obcy, a zachowanie płynności finansowej jest równie ważne jak odpowiednia ilość kapitału. Ewidencja księgowa w średniowiecznych Włoszech składała się z trzech ksiąg: memoriału, dziennika i księgi głównej. Istniało również pojęcie inwentarza, czyli spisu rzeczy posiadanych. Pacioli [2007 (1494)] sugerował, aby sporządzać inwentarz według malejącej płynności (odwrotnie niż obecna struktura bilansu, np. według ustawy o rachunkowości). W dziele Włocha można również odnaleźć zalążki kontrolnej funkcji rachunkowości oraz troskę o rzetelne prowadzenie ksiąg. Technika przenoszenia zapisów dziennika do księgi głównej, zasada podwójnego zapisu, równość sumy bilansowej: aktywów i pasywów oraz kategoria storna, również wprowadzona już w dziele Paciolego, pozostały niezmienne do dziś. Ponad 500 lat temu istniały już wskazówki dotyczące obiegu i rejestrowania dokumentów. Warto również zwrócić uwagę, że to wielkie dzieło, stanowiące oprócz teorii rachunkowości także zbiór praktycznych wskazówek co do zastosowania rachunkowości, w swojej strukturze jest podobne do współczesnych międzynarodowych standardów rachunkowości: zawiera cel i zakres stosowania, a następnie szczegółowo opisuje sposoby postępowania, przeplatając je praktycznymi przykładami zastosowań. Dzieło Luki Paciolego jest uznawane za jedno z największych osiągnięć rachunkowości do czasów rewolucji przemysłowej [Dobija i Jędrzejczyk 2011].

\section{Rachunek kosztów jako odpowiedź na zapotrzebowanie sprawozdawcze kapitalistów}

W XVII w. europejski ośrodek handlu został przesunięty na północ - nad Atlantyk i Morze Północne, przez co również i rachunkowość zaczęła przenikać z Włoch do krajów Europy Zachodniej i Środkowej. W upowszechnianiu księgowości bardzo ważną rolę odegrał wydany w 1673 r. Ordonance de commerce, czyli Francuski kodeks handlowy. Prawo to nałożyło na kupców obowiązek prowadzenia ksiąg rachunkowych, sporządzania co dwa lata inwentarza oraz przechowywania przez 10 lat ksiąg i dokumentów handlowych.

Rachunek kosztów, który można nazwać nowym działem rachunkowości, mimo że przejawiał się już w księgowości XV-wiecznych manufaktur, rozwinął się w pełni dopiero dzięki rewolucji przemysłowej. To ona dała asumpt do zmiany księgowości w celu dostosowania jej do potrzeb kapitalistycznych przedsiębiorstw [Podstawy rachunkowości... 2006]. Narzędzia rachunku kosztów były stosowane na szeroką skalę: planowano i porównywano koszty zużycia materiałów, umiano wykorzystywać efekty skali i minimalizować jednostkowe koszty wytworzenia. 
Metody te można nazwać ówczesną formą controllingu. Przedsiębiorstwo Du Pont Powder Company na początku XX w. wprowadziło wskaźnik rotacji aktywów. Znane już również w tym czasie były zasady budżetowania. Literatura wskazuje jednak, że rozwój rachunku kosztów został zahamowany w 1925 r. i nie zmienił swej postaci przez ponad pół wieku. Spowodowane było to zapewne ogólnym zahamowaniem i brakiem rozwoju myśli ekonomicznej.

Pierwsi kapitalistyczni przedsiębiorcy niechętnie prezentowali informacje sprawozdawcze o swoich firmach, tym bardziej że nie istniało prawo, które nakładałoby na nich obowiązek ujawniania informacji księgowych. Wówczas problematykę finansowania przerzucano na bankierów. Działania takie okazały się nieskuteczne, dlatego w 1939 r. powołano CAP: Committee on Accounting Procedure. Ten organ miał odpowiadać za tworzenie oraz publikowanie standardów rachunkowości, które umożliwiłyby prezentację informacji finansowej na potrzeby inwestorów [Dobija i Jędrzejczyk 2011].

\section{Regulacje rachunkowości w historii Polski nowożytnej}

Przed rozbiorami Polska była pogrążona w wewnętrznym kryzysie ustrojowym. Kodeks handlowy wprowadzono w 1809 r. w Księstwie Warszawskim - był on stosowany aż do wydania polskiego Kodeksu handlowego, jednakże niektóre przepisy dotyczące rachunkowości zawarte w Kodeksie Napoleońskim są aktualne aż do dzisiaj [Turzyński 2011]. Kodeks handlowy nakładał na wszystkich kupców obowiązek prowadzenia ksiąg rachunkowych (lecz pozwalał na zwolnienie podmiotowe „małych przedsiębiorców”). Księgi należało przechowywać przez 10 lat, a składały się one z dziennika, corocznego inwentarza oraz kopii listów. Mimo że nie wymagało tego prawo, często prowadzone były także inne księgi: weksli, kasowe, wydatków, wypłat, kupna, sprzedaży, zysków i strat. Kodeks nakładał także obowiązek przygotowywania bilansów upadłościowych. Analizując przepisy napoleońskiego kodeksu handlowego, można stwierdzić, że jego podstawowym zadaniem było zapewnienie bezpieczeństwa prowadzenia obrotu gospodarczego. Podobną funkcję pełni obecnie m.in. badanie przez biegłych rewidentów sprawozdań finansowych.

W 1907 r., jeszcze pod zaborami, został powołany do życia Związek Buchalterów w Warszawie ${ }^{1}$. Pierwszym prezesem tego stowarzyszenia był Konrad Czerwiński. Tego samego roku ukazał się pierwszy numer dwutygodnika o nazwie „Kronika Buchaltera"” .

\footnotetext{
${ }^{1}$ http://www.skwp.pl/Kalendarium,1106.html (20.02.2013).

${ }^{2}$ http://www.skwp.poznan.pl/stowarzyszenie/ stowarzyszenie-ksiegowych-w-polsce-oddzialwielkopolski-w-poznaniu/historia-skwp (20.02.2013).
} 
W 1926 r. zmieniono nazwę stowarzyszenia na Związek Księgowych w Polsce i rozszerzono jego działalność na cały kraj (wcześniejszy Związek Buchalterów w Warszawie obejmował swym zasięgiem Królestwo Polskie). Natomiast w 1927 r. odbył się w Warszawie po raz pierwszy w Polsce Ogólnopolski Zjazd Księgowych. W 1939 r. okupant wydał zakaz prowadzenia działalności przez jakiekolwiek stowarzyszenia. Stowarzyszenie księgowych nie podporządkowało się w pełni temu zakazowi - nadal potajemnie działało, jednakże tylko w obrębie warszawskim ${ }^{3}$. Po zakończeniu II wojny światowej, 30 lipca 1946 r. zarejestrowane zostało Stowarzyszenie Księgowych w Polsce jako organizacja społeczna, która miała zrzeszać pracowników szeroko pojętego zawodu księgowego. Po trzech latach działalności komunistyczne władze podjęły decyzję o zlikwidowaniu tego stowarzyszenia. Ponadto dokonano zniszczenia całej dotychczasowej dokumentacji Związku Księgowych w Polsce. Członkowie zlikwidowanego stowarzyszenia zaczęli się zrzeszać w sekcjach rachunkowości w Polskim Towarzystwie Ekonomicznym. Księgowi zajmowali się m.in. ustalaniem jednolitego planu kont. W 1957 r. udało się reaktywować działalność stowarzyszenia: 4 marca zarejestrowano w Warszawie Stowarzyszenie Księgowych w Polsce (SKwP). Ta organizacja społeczna miała mieć zasięg ogólnopolski i zrzeszać ludzi związanych z zawodem księgowego. Między innymi z powodu braków środków finansowych stowarzyszenie oprócz zrzeszania księgowych podjęło się także funkcji szkoleniowej. Po 1989 r., kiedy to wprowadzono nowe uregulowania prawne dotyczące zasad rachunkowości i zasad pracy biegłych rewidentów, wzrosły potrzeby i zakres działalności edukacyjnej prowadzonej przez SKwP. W 1989 r. Krajowa Rada Dyplomowanych Biegłych Księgowych, która została powołana przez Stowarzyszenie, została przyjęta do IFAC: Międzynarodowej Federacji Księgowych, natomiast w 1996 r. stowarzyszenie zostało przyjęte do Europejskiej Federacji Księgowych i Audytorów Małych i Średnich Przedsiębiorstw: EFAA.

Ciągły rozwój gospodarki i dokonujące się zmiany powodują, że rośnie liczba szkoleń prowadzonych przez SKwP. Stowarzyszenie podjęło się również wprowadzania certyfikacji zawodu księgowego w Polsce.

\section{Rozwój badań naukowych w zakresie rachunkowości}

Dzieło Luki Paciolego zainspirowało innych matematyków i badaczy do napisania i wydania kolejnych książek traktujących o rachunkowości, m.in. Girolamo Cardano, Giovanniego Antonia Taglientego, Bartolomeo Fontanę, Domenica Manzoniego czy Alvisego Casanovę. Po raz pierwszy specyfikę organizacji nienastawionych na osiągnięcie zysku, czyli tych zwanych obecnie organiza-

\footnotetext{
${ }^{3}$ http://www.skwp.pl/Kalendarium,1106.html (20.02.2013).
} 
cjami pożytku publicznego, wprowadzili mnisi: Angelo Pietra i Ludovico Flori. Natomiast pierwszym krajem, który administracyjnie uregulował rachunkowość podwójną, była Hiszpania. Zasada ostrożnej wyceny po raz pierwszy pojawiła się we Francji w książce Jacquesa Savary w 1675 r. [Dobija i Jędrzejczyk 2011]. W końcu XVIII w. powstało kolejne bardzo ważne w historii rachunkowości dzieło: La tenue des livres reduce facile Edmonda Degrange'a [1975]. Dokonał on systematyzacji wiedzy o rachunkowości, wprowadzając nazwę „rachunkowość podwójna”. Rachunkowość rozwijała się najbardziej w XX w., ciągle ewoluując w odpowiedzi na globalizację, wzrost wolumenu transakcji gospodarczych, rozwój technologii informatycznych. Nowe trendy w rachunkowości zapoczątkował w 1986 r. Y. Ijiri [1986], formułując teorię potrójnego księgowania, która poszerzyła system księgowy o konta wynikowe.

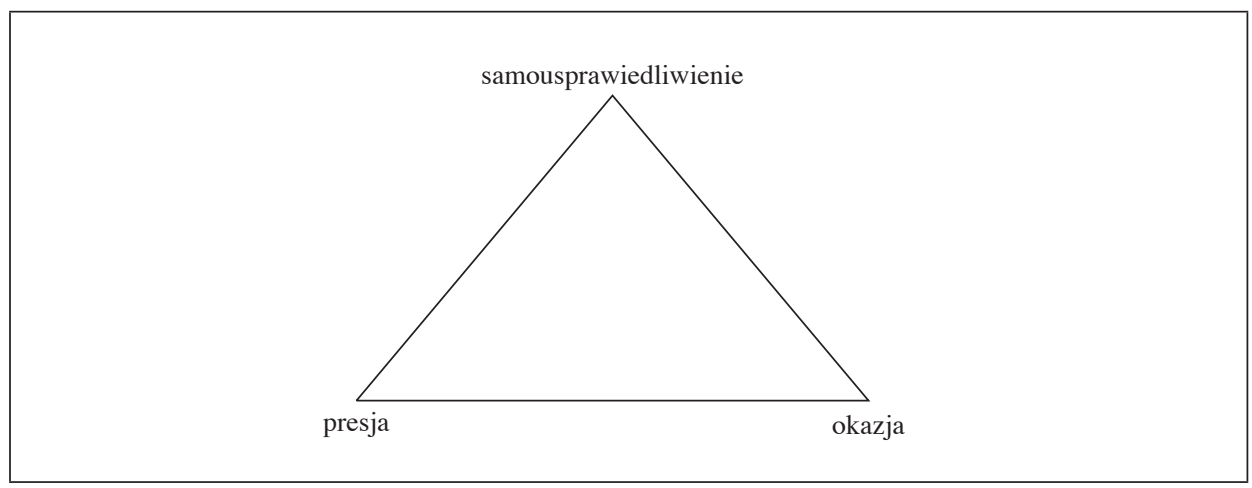

Rys. 1. Trójkąt oszustw

Źródło: [Wells 2006, s. 23].

Niestety, równolegle do rachunkowości rozwijała się również oszukańcza sprawozdawczość finansowa. Analiza literatury wskazuje, że oszustwom finansowym poświęcano stosunkowo niewiele uwagi w badaniach naukowych, a jeżeli już to czyniono, to najczęściej w nurcie kryminologii [Kutera 2008]. Pionierem w badaniach nad oszukańczą rachunkowością był właśnie amerykański kryminolog E.T. Sutherland, który jako pierwszy w 1939 r. użył określenia „przestępstwa białych kołnierzyków". Prowadził on badania nad nadużyciami, których dopuszczali się dyrektorzy finansowi na szkodę akcjonariuszy. Kontynuatorem pracy nad oszukańczą sprawozdawczością był D. Cressey, który opracował znaną teorię wyjaśniającą istotę nadużyć finansowych: tzw. trójkąt oszustw. Trójkąt obrazuje trzy czynniki, których równoczesne zajście niemalże gwarantuje zaistnienie oszustwa. Aby doszło do oszustwa, musi być ku temu okazja. Drugi element to presja, a trzeci element trójkąta oszustw to samousprawiedliwienie. Jeżeli ktoś 
jest skłonny do samousprawiedliwienia i odczuwa presję, lecz nie ma okazji do oszustwa, to do oszustwa nie dojdzie. Podobnie - jeśli ktoś ma okazję, jest presja, lecz moralność nie pozwala mu na dokonanie oszustwa - to nie dojdzie do niego. Model trójkąta oszustw stał się teorią, którą często można spotkać w literaturze za zakresu analizy przestępczości gospodarczej.

Kolejne badania nad oszustwami finansowymi przeprowadzali w latach 80 . XX w. m.in. S. Albrecht, K. Howe i M. Romney [Wells 2006]. Zgromadzili oni informacje o ponad dwustu oszustwach zidentyfikowanych przez audytorów zewnętrznych. Poprzez analizę pobudek prowadzących do dokonania oszustwa wyspecyfikowali oni 80 sygnałów ostrzegawczych. Stworzyli także tzw. skalę oszustw, która była rozwinięciem teorii trójkąta oszustw. W kolejnych latach badania, głównie ankietowe, prowadzili R.C. Hollinger i J.P. Clark, a także od 1996 r. Stowarzyszenie Biegłych ds. Przestępstw i Nadużyć Gospodarczych [Kutera 2008].

Afery finansowe wielkich spółek z początku XXI w. (Enron, WorldCom, Xerox, Friede Max czy Parmalat), które miały swój udział w destabilizacji rynków finansowych poprzez utratę zaufania inwestorów do rynków i biegłych rewidentów, ukazały istotność nauki i badań w kwestii oszukańczej sprawozdawczości finansowej oraz jej wpływ na występowanie globalnych sytuacji kryzysowych.

\section{Historia zawodu biegłego rewidenta}

Zawód biegłego rewidenta ma ponadpięciowiekową tradycję, a jego początków należy szukać w Italii. W Wenecji, w $1581 \mathrm{r}$. został założony pierwszy związek zawodowych księgowych [Green 1930]. Jego zadaniem było ustalenie zasad wykonywania zawodu księgowego oraz kwalifikacji niezbędnych do jego wykonywania. Były to pierwsze próby unifikacji zawodu księgowego. Natomiast w 1906 r. prawo włoskie po raz pierwszy uznało zawód księgowego rzeczoznawcy [Pogodzińska-Mizdrak 2006]. Eksperci ci byli nie tylko powoływani do wyceny majątku, ale również mieli prawo występowania jako biegli sądowi, rewizji ksiąg, a także zarządzania masą upadłościową. Stosunkowo wcześnie zawód biegłego rewidenta pojawił się na wyspach brytyjskich, gdzie w XVIII w. działali dyplomowani księgowi [Pogodzińska-Mizdrak 2006]. Pod koniec XVII w. było ich w Anglii ponad 50 [Micherda 2005]. W 1844 r. ustawa o spółkach wprowadziła w Wielkiej Brytanii obowiązek badania bilansu, natomiast w 1854 r. został usankcjonowany w Szkocji zawód biegłego rewidenta: chartered accountant, a w 1880 r. utworzono instytut biegłych księgowych: The Institute of Chartered Accountants of England and Wales. Instytucję biegłego rewidenta w podobnym czasie powołano również w Holandii, jednakże tam, w przeciwieństwie do rozwiązań zastosowanych w Anglii, zawód ten nie uzyskał prawnej ochrony. W Niemczech do 1900 r. 
biegłych rewidentów mianowały sądy, we Francji w 1912 r. powstał Związek Biegłych Rzeczoznawców, w Belgi w 1903 r. powołano Izbę Związkową Buchalterów, a w Austrii w 1904 r. powstało Stowarzyszenie Buchalterów Rzeczoznawców [Jędral i Nowakowski 1937]. Natomiast w Stanach Zjednoczonych w 1887 r. powstało Amerykańskie Stowarzyszenie Biegłych Rewidentów: American Association of Public Accountants [Don Edwards 1960]. W 1896 r. usankcjonowano w stanach Amerykański Związek Dyplomowanych Biegłych Rewidentów: The American Society of Certified Public Accountants. Aby otrzymać status biegłego rewidenta, trzeba było zdać państwowy egzamin, a nieuprawnione posługiwanie się tym tytułem było surowo karane. Rada Rezerwy Federalnej prowadzi od 1917 r. oficjalny rejestr biegłych rewidentów. Po kryzysie ekonomicznym w 1933 r. wprowadzono w USA obligatoryjne badanie przez biegłych rewidentów sprawozdań spółek giełdowych [Hendriksen i van Breda 2002].

Na terenach Polski w 1904 r. doszło do przekształcenia Koła Buchalterów w nieformalny Związek Księgowych w Polsce. Po 1918 r. mimo braku usankcjonowania prawnego praktyka wyraźnie odróżniała zawód księgowego od rewizji finansowej. Po raz pierwszy określono w Polsce status biegłych rewidentów w 1927 r. w Rozporządzeniu o instytucji księgowych przysięgłych [Pogodzińska-Mizdrak 2006]. Funkcja biegłego rewidenta w Polsce w okresie dwudziestolecia międzywojennego była bardzo wysoko ceniona [Góra 1931]. W czasach gospodarki nakazowej, z racji braku dóbr prywatnych zawód biegłego rewidenta stracił rację bytu. Dopiero w 1991 r. uchwalono ustawę o badaniu i ogłaszaniu sprawozdań finansowych oraz biegłych rewidentach i ich samorządzie, a od 1994 r. wprowadzano kolejne ustawy o biegłych rewidentach i ich samorządzie. Najnowsza taka ustawa została przyjęta w $2009 \mathrm{r}$.

Na przestrzeni wieków zmieniały się zarówno cele, jak i metody badania sprawozdań finansowych. Początkowo, pod koniec XIX w., głównym celem badania było jedynie wykrywanie potencjalnych oszustw i błędów [Micherda 2010]. W niedługim czasie pojawił się drugi cel, a mianowicie weryfikacja merytoryczna zapisów księgowych, jednakże podstawowy cel pozostał ten sam. Dopiero w latach 20. XX w. wyróżniono trzeci cel badań sprawozdań finansowych - było nim potwierdzenie wiarygodności sprawozdania finansowego. Miała tego potwierdzenia dokonać niezależna, obiektywna osoba: biegły rewident. Wkrótce, w odpowiedzi na potrzeby inwestorów ten trzeci cel badania sprawozdania finansowego stał się celem głównym [Hołda 1998].

\section{Podsumowanie}

Geneza rachunkowości sięga czasów prehistorycznych, kiedy to jej prowadzenie polegało na ilościowym ujmowaniu początkowych, najprostszych zdarzeń 
gospodarczych. Rachunkowość, mająca na celu pomiar aktywności gospodarczej, zawierała esencję myśli ekonomicznej już w czasach prehistorycznych, w samych początkach powstania ludzkiej cywilizacji. Wraz z postępem gospodarczym miał miejsce ciągły proces doskonalenia rachunkowości i rozszerzania jej zakresu. We współczesnej rachunkowości wykonuje się o wiele więcej czynności i zadań niż dawniej. Obok ewidencji rachunkowość zajmuje się także grupowaniem zdarzeń w rozmaitych przekrojach, ich prezentacją, a także interpretacją. Z produktów rachunkowości korzystają rzesze odbiorców: inwestorzy, akcjonariusze, banki, władze państwowe, urzędy skarbowe, kontrahenci, klienci, pracownicy, kadra zarządzająca, kierownicy i wiele innych podmiotów.

Rachunkowość to jedna z najstarszych dyscyplin wśród nauk ekonomicznych, która zawsze odgrywała dużą rolę w praktyce gospodarczej. Jest to najstarszy system ewidencji gospodarczej, którego założenia wytrzymały próbę czasu [Messner i Pfaff 2004].

\section{Literatura}

Alexander J.R. [2002], History of Accounting, Association of Chartered Accountants in the United States, New York.

Dobija M., Jędrzejczyk M. [2011], Szkice z historii rachunkowości, Polskie Towarzystwo Ekonomiczne, Kraków.

Don Edwards J. [1960], History of Public Accounting in the United States, Michigan State University Press, East Lansing.

Góra W. [1931], Rola eksperta - księgowego w życiu gospodarczym, „Czasopismo Księgowych w Polsce", nr 9.

Green W.L. [1930], History and Survay of Accountancy, New York.

Hendriksen E.A., van Breda M.F. [2002], Teoria rachunkowości, PWN, Warszawa.

Hołda A. [1998], Ewolucja auditingu i jego rola w gospodarce rynkowej, Zeszyty Naukowe Akademii Ekonomicznej w Krakowie, nr 514, Kraków.

Ijiri Y. [1986], A Framework for Triple-entry Bookkeeping, „The Accounting Review”, October.

Jędral W., Nowakowski J. [1937], O biegłych rewidentach z zakresu księgowości, Stowarzyszenie Biegłych i Rewizorów Ksiąg Handlowych ustanowionych i zaprzężonych przez Izbę Przemysłowo-Handlową w Katowicach, Katowice.

Krawczuk A. [1995], Siedmiu przeciw Tebom, Wydawnictwo Poznańskie, Poznań.

Kutera M. [2008], Rola audytu finansowego w wykrywaniu przestępstw gospodarczych, Difin, Warszawa.

Messner Z., Pfaff J. [2004], Rachunkowość finansowa, Stowarzyszenie Księgowych w Polsce, Warszawa.

Micherda B. [2001], Ocena działalności jednostek gospodarczych przesłanka ewolucji rachunkowości i jej regulacji prawnych, Zakamycze, Kraków.

Micherda B. [2005], Badanie sprawozdania finansowego w perspektywie historycznej, Zeszyty Naukowe Akademii Ekonomicznej w Krakowie, nr 674, Kraków. 
Micherda B. [2010], Współczesny rozwój rachunkowości i jego uwarunkowania. Perspektywy rozwoju rachunkowości i sprawozdawczości finansowej, Uniwersytet Ekonomiczny w Krakowie, Kraków.

Pacioli L. [2007 (1494)], Summa di arithmetica, geometria, proportioni et propotrionalita, Stowarzyszenie Księgowych w Polsce, Warszawa 2007.

Podstawy rachunkowości [2006], red. K. Sawicki, Polskie Wydawnictwo Ekonomiczne, Warszawa.

Pogodzińska-Mizdrak E. [2006], Zawód biegłego rewidenta - rys historyczny, Zeszyty Naukowe Akademii Ekonomicznej w Krakowie, nr 702, Kraków.

Schmandt-Besserat D. [2007], When Writing Met Art. From Symbol to Story, University of Texas Press, Austin.

Struwe W. [1969], Some New Data on the Organisation of Labour and on Social Structure in Sumer during the Reign of the IIIrd Dynasty of Ur [w:] Ancient Mesopotamia, Nauka, Moskwa

Tumieniew A. [1969] The State Economy of Ancient Sumer [w:] Ancient Mesopotamia, Nauka, Moskwa.

Turzyński M. [2011], Regulacje rachunkowości w Kodeksie handlowym z 1807 r. i Kodeksie cywilnym Napoleona, ,Rachunkowość”, nr 3.

Wells J.T. [2006], Nadużycia w firmach. Vademecum, Ernst \& Young, Warszawa.

\section{The History of Accounting - One of the Oldest Economic Disciplines}

It is possible to find signs of accounting as far back as prehistoric times, when it constituted the essence of the then contemporary economic thought and solved problems involved in joint labour. This publication presents the history of accounting from the first bookkeeping account through Luca Pacioli's work that is so crucial to the history of accounting and, finally, the evolution of the bill of charges that was created for the needs of the first capitalists. Research on the system of accounting is presented, as are deceitful financial reporting and the establishment of the profession of Chartered Accountants. The history of accounting shows that it is one of the oldest disciplines of economic studies and, most importantly, the foundations of accounting have stood the test of time. The structure of a bookkeeping account with a Dt and $\mathrm{Ct}$ page has remained unchanged for over five thousand years.

Keywords: accounting, account, rule of double entry, history of economics. 